\title{
Granulocyte colony-stimulating factor potentiates differentiation induction by all-trans retinoic acid and arsenic trioxide and enhances arsenic uptake in the acute promyelocytic leukemia cell line HT93A
}

\author{
NORIYOSHI IRIYAMA $^{1^{*}}$, BO YUAN $^{2^{*}}$, YOSHIHIRO HATTA $^{1}$, AKIRA HORIKOSHI $^{3}$, \\ YUTA YOSHINO $^{2}$, HIROO TOYODA ${ }^{2}$, SHIN AIZAWA ${ }^{4}$ and JIN TAKEUCHI ${ }^{1}$

\begin{abstract}
${ }^{1}$ Department of Hematology and Rheumatology, Itabashi Hospital, Nihon University School of Medicine, Itabashi-ku, Tokyo 173-8610; ${ }^{2}$ Department of Clinical Molecular Genetics, Tokyo University of Pharmacy and Life Sciences, Hachioji, Tokyo 192-0392; ${ }^{3}$ Department of Internal Medicine, Nerima-Hikarigaoka Hospital, Nihon University School of Medicine, Nerima-ku, Tokyo 179-0072; ${ }^{4}$ Department of Functional Morphology, Nihon University School of Medicine, Itabashi-ku, Tokyo 173-8610, Japan
\end{abstract}

Received May 29, 2012; Accepted July 16, 2012

DOI: $10.3892 /$ or.2012.2006

\begin{abstract}
The effects of arsenic trioxide (ATO), all-trans retinoic acid (ATRA) and granulocyte colony-stimulating factor (G-CSF), alone or in combination, were investigated by focusing on differentiation, growth inhibition and arsenic uptake in the acute promyelocytic leukemia (APL) cell line HT93A. ATO induced differentiation at low concentrations $(0.125 \mu \mathrm{M})$ and apoptosis at high concentrations (1-2 $\mu \mathrm{M})$. Furthermore, ATRA induced greater differentiation than ATO. No synergistic effect of ATRA and ATO was found on differentiation. G-CSF promoted differentiation-inducing activities of both ATO and ATRA. The combination of ATRA and G-CSF showed maximum differentiation and ATO addition was not beneficial. Addition of $1 \mu \mathrm{M}$ ATRA and/or $50 \mathrm{ng} / \mathrm{ml} \mathrm{G-CSF}$ to ATO did not affect apoptosis compared to ATO treatment alone. ATRA induced expression of aquaporin-9 (AQP9), a transmembrane transporter recognized as a major pathway of arsenic uptake, in a time- and dose-dependent manner. However, treatment with $1 \mu \mathrm{M}$ ATRA decreased arsenic uptake by $43.7 \%$ compared to control subject. Although G-CSF addition did not enhance AQP9 expression in the cells, the reduced arsenic uptake was recovered to the same level as that in controls. ATRA decreased cell viability and addition of $50 \mathrm{ng} / \mathrm{ml} \mathrm{G}-\mathrm{CSF}$ to ATRA significantly increased the number
\end{abstract}

Correspondence to: Dr Yoshihiro Hatta, Department of Hematology and Rheumatology, Itabashi Hospital, Nihon University School of Medicine, 30-1 Oyaguchi Kamicho, Itabashi-ku, Tokyo 173-8610, Japan

E-mail: hatta.yoshihiro@nihon-u.ac.jp

*Contributed equally

Key words: acute promyelocytic leukemia, arsenic trioxide, all-trans retinoic acid, granulocyte colony-stimulating factor, HT93A, aquaporin-9, differentiation of viable cells compared with that in ATRA alone treated cells. G-CSF not only promotes differentiation-inducing activities of both ATRA and ATO, but also makes APL cells vulnerable to increased arsenic uptake. These observations provide new insights into combination therapy using these three agents for the treatment of APL.

\section{Introduction}

Acute promyelocytic leukemia (APL) is characterized by a balanced reciprocal translocation between chromosome 15 and 17 , resulting in the fusion of the promyelocytic leukemia (PML) and retinoic acid receptor genes (1-3). All-trans retinoic acid (ATRA) has become the first-line treatment for patients with APL due to its high clinical complete remission rate $(4,5)$. For patients with relapsed or refractory APL who are resistant to the conventional treatment protocols, a new arsenic-based therapy has been established. Previous clinical studies demonstrated that $90 \%$ of relapsed patients achieved remission by treatment with arsenic trioxide (ATO) $(6,7)$.

NB4, the first APL cell line with $\mathrm{t}(15 ; 17)$, was established from marrow samples obtained from a patient with APL receiving retinoic acid (8). NB4 has been widely used to investigate the cellular and molecular mechanisms of ATRA and ATO (9-14). Cell biology studies using NB4 and APL blasts obtained from patients have revealed that ATO exerts dose-dependent dual effects on APL cells. Apoptosis is induced when cells are treated with 1.0-2.0 $\mu \mathrm{M}$ ATO, while partial differentiation is observed when low concentrations (0.1-0.5 $\mu \mathrm{M})$ are used $(13,14)$. Aquaporin-9 (AQP9), a transmembrane transporter belonging to aquaporin superfamily, has been recognized as a major pathway of arsenic uptake, and its expression is associated with ATO sensitivity in either leukemia cells (12) or human-derived normal cells (15). Although several investigators reported that ATRA induced AQP9 expression (12), ATO incorporation has not been 
investigated well when these two agents are concomitantly administered.

Myeloid growth factors such as granulocyte colonystimulating factor (G-CSF) promote proliferation, survival and differentiation of leukemic cells $(9,16,17)$. Although it remains controversial whether G-CSF alone induces differentiation in APL blasts, differentiation induction in APL cells by ATRA could be enhanced by G-CSF in vitro and in vivo $(9,11,17)$. Furthermore, a previous report has demonstrated that the differentiation-inducing activities of ATRA and ATO were abrogated by specific G-CSF neutralization, suggesting a requirement for G-CSF for differentiation of APL cells (9).

Although clinical analyses revealed the effectiveness of combination treatment with ATO and ATRA $(18,19)$, its efficacy and mechanisms of the combination administration are not yet well understood. In this study, we examined the effect of ATO, ATRA and G-CSF alone or in combination on HT93A cells. While most of in vitro experiments on APL have been conducted using NB4 cells, another t(15;17)-positive APL cell line, HT93A, was used for this study. HT93A was obtained from peripheral blood of an APL patient without receiving ATRA or ATO (20-23). Cellular responses to ATRA or ATO treatment in HT93A cells may be different from those in NB4 cells since diverse cell types with distinct characteristics exist in individual patient with different clinical background, although both possess $t(15 ; 17)$.

Therefore, we investigated the alterations in morphology, cell surface markers, apoptosis and AQP9 expression in HT93A cells treated with ATRA or ATO in the presence or absence of G-CSF. We also attempted to investigate the contribution of G-CSF to the differentiation induction by ATRA or ATO. Our data suggest the enhanced differentiation induction of combination treatment with ATRA+G-CSF or $\mathrm{ATO}+\mathrm{G}-\mathrm{CSF}$ in APL.

\section{Materials and methods}

Reagents. ATO was purchased from Sigma (St. Louis, MO, USA) and dissolved in $1 \mathrm{M}$ sodium hydroxide solution, diluted with phosphate-buffered saline (PBS), sterilized by filtration $(0.22-\mu \mathrm{m}$ filter) and used as the stock solution. Recombinant human G-CSF (Filgrastim) was obtained from Kyowa Hakko Kirin Co, Ltd. (Tokyo, Japan) and dissolved in PBS to prepare the stock solution and stored at $4^{\circ} \mathrm{C}$ until use. ATRA was purchased from Sigma and dissolved in ethanol to obtain a final concentration of $2 \mathrm{mM}$ and stored at $-20^{\circ} \mathrm{C}$ in the dark. The vehicle reagent, ethanol (final concentration $<0.05 \%$ ), did not affect cell viability and differentiation. Phycoerythrin (PE)-conjugated mouse anti-human CD11b $\operatorname{IgG}_{2 \alpha}$ and CD34 $\mathrm{IgG}_{1}$ as well as fluorescein isothiocyanate (FITC)conjugated mouse anti-human CD15 IgM were used for the assessment of differentiation induction and were obtained from Beckton-Dickinson (San Jose, CA, USA). FITCconjugated mouse anti-human $\mathrm{CD} 11 \mathrm{c} \mathrm{IgG}_{1}$ was obtained from eBioscience, Inc. (San Diego, CA, USA). Anti-rat AQP9 antibody (rabbit) was purchased from Alpha Diagnostic International, Inc. (San Antonio, TX, USA). The Apoptosis Detection kit I containing annexin V-FITC, propidium iodide (PI) and 10X annexin $\mathrm{V}$ binding buffer was purchased from Beckton-Dickinson.
Cell culture and treatment. HT93A, a human APL cell line established from peripheral blood of a patient with APL (16), was provided from Dr Kenji Kishi (Shibata Hospital, Shibata, Japan) and Dr Yuko Sato (National Center for Global Health and Welfare, Japan). HT93A was maintained in RPMI-1640 medium (Gibco-BRL, Grand Island, NY, USA) supplemented with $10 \%$ heat-inactivated fetal bovine serum (FBS) (Gibco-BRL), $100 \mathrm{U} / \mathrm{ml}$ penicillin and $100 \mu \mathrm{g} / \mathrm{ml}$ streptomycin (Gibco-BRL) at $37^{\circ} \mathrm{C}$ in a humidified atmosphere $\left(5 \% \mathrm{CO}_{2}\right.$ in air). Cells were seeded at a density of $1 \times 10^{5}$ cells $/ \mathrm{ml}$ and treated with ATO, ATRA and G-CSF, alone or in combination. Cell viability was assessed by the trypan blue exclusion assay.

Determination of apoptosis. Apoptosis was analyzed using the Apoptosis Detection kit I according to the manufacturer's instructions. In brief, cells were washed twice with cold PBS and then resuspended in $1 \mathrm{X}$ annexin $\mathrm{V}$ binding buffer. After annexin V-FITC/PI staining for $15 \mathrm{~min}$ at room temperature in the dark, the cells were analyzed using flow cytometry (Cyto ACE-150; Jasco, Tokyo, Japan) within $1 \mathrm{~h}$. The percentage of apoptotic cells was determined by annexin V/PI staining. The sum total of early apoptotic cells, annexin V (+) PI (-), and late apoptotic cells, annexin V (+) PI (+), was regarded as the total number of apoptotic cells. Cells were considered viable if they did not show annexin V/PI staining.

Differentiation analysis. Differentiation induction was confirmed by morphology and expression of surface markers. For morphological assessment, cytospin preparations of treated cells stained with Wright-Giemsa were evaluated by light microscopy. Myeloid maturation with cell surface markers was analyzed by flow cytometry (Cyto ACE-150; Jasco) using antibodies for CD11b, CD11c, CD15 and CD34 as previously described with minor modifications (16). In brief, $\sim 1 \times 10^{6}$ cells were washed with PBS containing 2.5\% FBS and $0.5 \% \mathrm{NaN}_{3}$ (PBSF) and stained with PE-conjugated mouse anti-human CD11b $\mathrm{IgG}_{2 \alpha}$ and CD34 $\mathrm{IgG}_{1}$, FITC-conjugated mouse antihuman CD15 IgM and FITC-conjugated mouse anti-human CD11c $\mathrm{IgG}_{1}$ for $30 \mathrm{~min}$ at $4^{\circ} \mathrm{C}$ in the dark. Cells were then washed 3 times with PBSF and analyzed by flow cytometry with a minimum acquisition of 10,000 events. Non-binding mouse IgG-PE, IgG-FITC or IgM-FITC isotype antibodies (Beckton-Dickinson) were used as controls.

Analysis of AQP9 expression. Cells were harvested and washed with PBSF, followed by staining with rabbit anti-rat AQP9 antibody at a concentration of $10 \mu \mathrm{g} / \mathrm{ml}$ for $30 \mathrm{~min}$ at $4^{\circ} \mathrm{C}$ in the dark. After washing 3 times with PBSF, the cells were stained with FITC-conjugated goat anti-rabbit antibody and analyzed by flow cytometry. Immunostaining specificity was controlled by omission of primary or secondary antibodies.

Analysis of intracellular arsenic accumulation (As[intra]). Cells were harvested and counted to give accurate viable cell numbers, which were used to normalize As[intra]. After washing 3 times with PBS, the cells were pelleted by centrifugation and stored at $-20^{\circ} \mathrm{C}$ until analysis. After transfer to $15-\mathrm{ml}$ polypropylene centrifuge tubes, cell pellets were mixed with $\mathrm{HNO}_{3}(0.1 \mathrm{ml})$ at room temperature for $10 \mathrm{~min}$, and incubated at 
Table I. Profile of surface antigen expression in HT93A cells before and after ATRA treatment.

\begin{tabular}{|c|c|c|c|c|}
\hline Antigens & Clones & Positivity of control (\%) & $\begin{array}{c}\text { Positivity after } \\
\text { ATRA treatment }(\%)\end{array}$ & $\begin{array}{l}\text { Differentiation marker } \\
\text { expression }\end{array}$ \\
\hline CD2 & MT910 & 0.4 & 0.7 & \\
\hline CD3 & SK7 & 0.8 & 1.0 & \\
\hline CD4 & SK3 & 0.1 & 0.1 & \\
\hline CD5 & $53-7.3$ & 0.3 & 1.1 & \\
\hline CD7 & M-T701 & 0.6 & 0.9 & \\
\hline CD8 & SK-1 & 0.4 & 0.8 & \\
\hline CD10 & HI10a & 0.2 & 0.1 & \\
\hline CD11b & D12 & 0.3 & 13.6 & Upregulated \\
\hline CD11c & S-HCL-3 & 0.4 & 16.9 & Upregulated \\
\hline CD13 & L138 & 0.3 & 3.2 & \\
\hline CD14 & М $\phi \mathrm{P} 9$ & 0.1 & 6.7 & \\
\hline CD15 & MMA & 19.4 & 44.5 & Upregulated \\
\hline CD16 & NKP15 & 0.4 & 0.4 & \\
\hline CD19 & $4 \mathrm{G} 7$ & 0.5 & 0.8 & \\
\hline CD20 & L27 & 0.2 & 0.1 & \\
\hline CD33 & WM53 & 99.0 & 99.5 & \\
\hline CD34 & $8 \mathrm{G} 12$ & 66.2 & 30.9 & Downregulated \\
\hline CD41 & HIP8 & 0.6 & 7.6 & \\
\hline CD56 & MY31 & 99.5 & 99.8 & \\
\hline CD117 & YB5.B8 & 0.4 & 0 & \\
\hline KORSA & KOR-SA3544 & 0.2 & 0.5 & \\
\hline HLA-DR & L243 & 0.4 & 4.6 & \\
\hline MPO & MPO-7 & 2.4 & 2.3 & \\
\hline
\end{tabular}

HT93A cells were treated with or without $1 \mu \mathrm{M}$ ATRA for 8 days. Assessment of variable surface antigen expression by flow cytometry was entrusted to Bio Medical Laboratories, Inc. (BML, Inc., Tokyo, Japan).
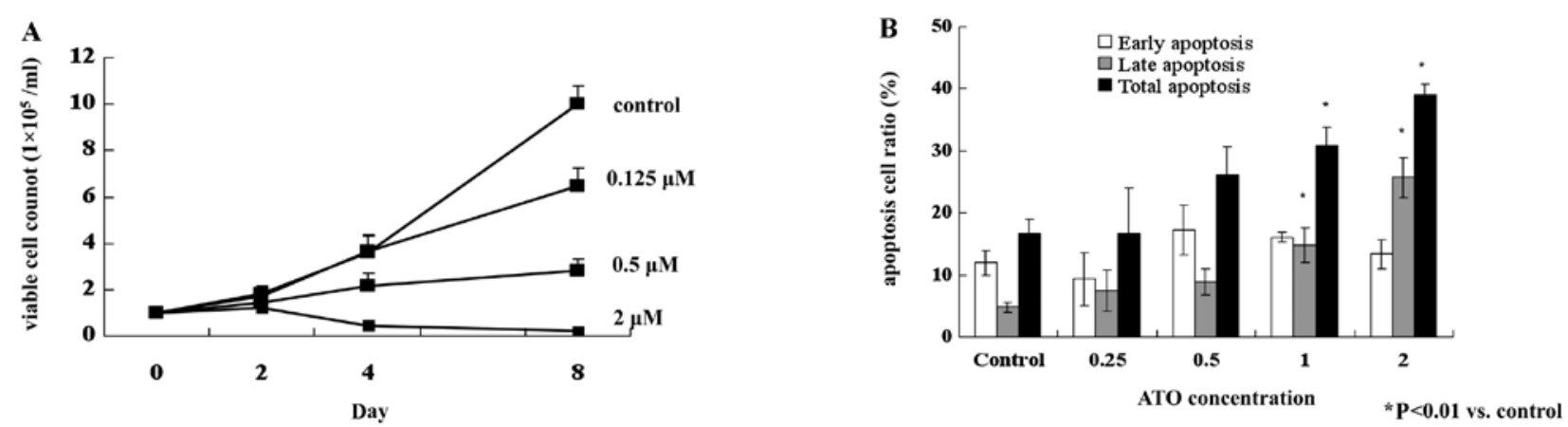

Figure 1. Effects of ATO on cell growth and apoptosis induction in HT93A cells. (A) HT93A cells were treated with 0.125-2 $\mu$ M ATO for 2-8 days and viable cell number was calculated by the trypan blue exclusion assay. (B) After treatment with 1 and $2 \mu \mathrm{M}$ ATO for 4 days, apoptosis induction was determined by PI/ annexin V staining. Experiments were performed three times and results are shown as mean \pm SD. ${ }^{P}<0.01$ vs. control by Student's t-test.

$80^{\circ} \mathrm{C}$ on a hot plate for $90 \mathrm{~min}$. The cell suspension was diluted with Milli-Q water to $3 \mathrm{ml}$ and analyzed using inductively coupled plasma mass spectrometry (ICP-MS) (ELAN ${ }^{\circledR}$ DRC-e; PerkinElmer SCIEX, Ontario, Canada) for total arsenic determination, as described previously (24).

Statistical analysis. Experiments were independently repeated and results are shown as mean \pm standard deviation (SD) of 3 assays. A two-tailed, paired Student's t-test or Mann-
Whitney U test was used and a P-value $<0.05$ was considered to be significant.

\section{Results}

Growth inhibition and apoptosis by ATO in HT93A cells. First, we investigated whether HT93A cells showed sensitivity to ATO treatment. ATO inhibited growth of HT93A cells in a dose-dependent manner (Fig. 1A). After treatment with ATO 


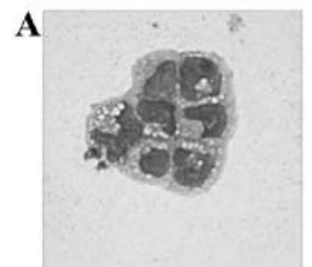

Control

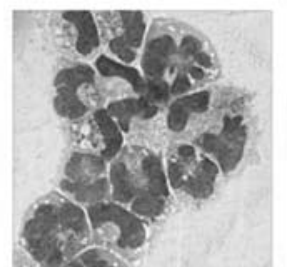

ATRA

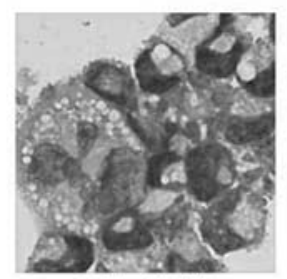

ATO+G-CSF

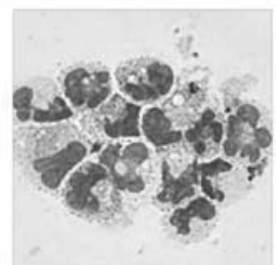

ATRA+G-CSF

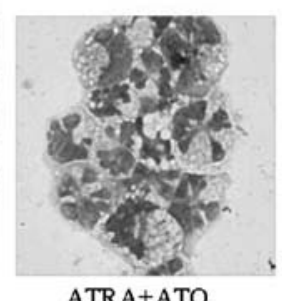

ATRA+ATO

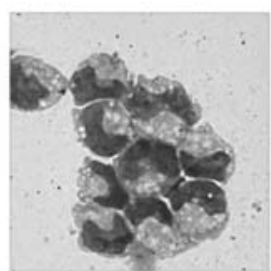

ATO

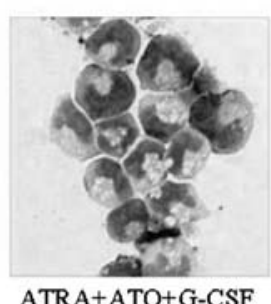

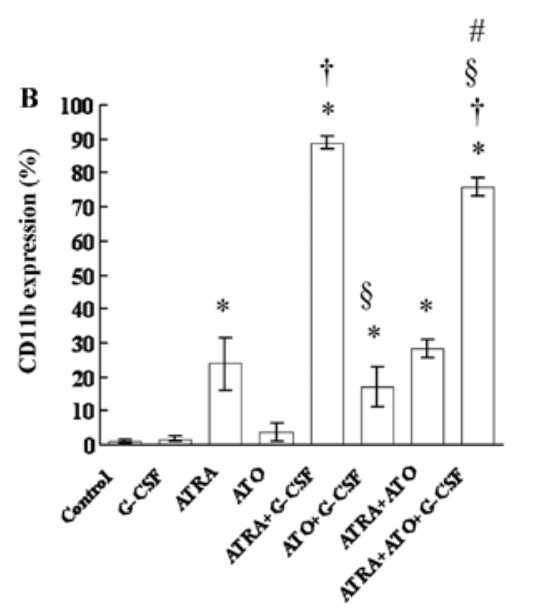
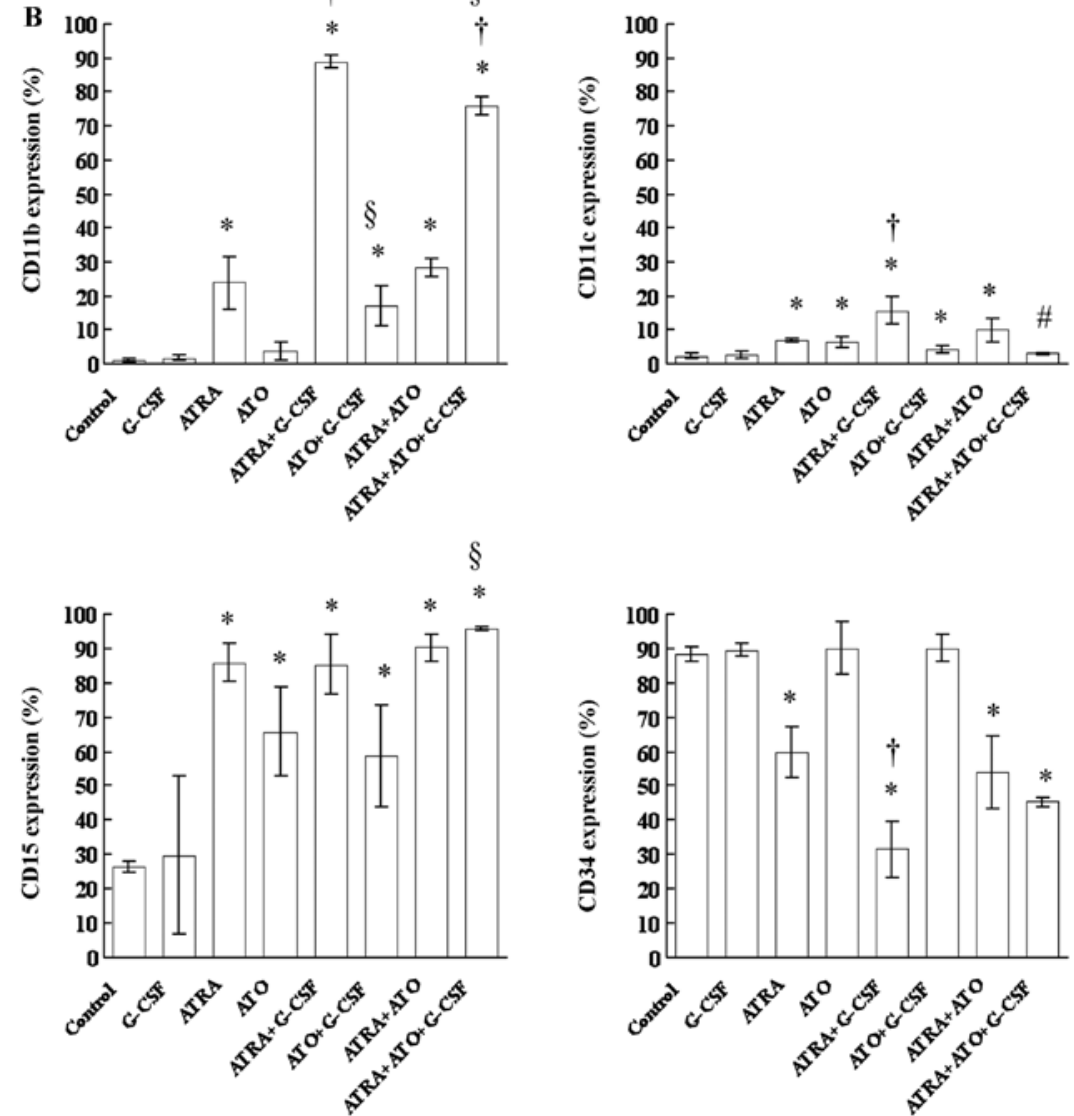

Figure 2. Differentiation profile of surface antigen expression and morphological changes in HT93A cells treated with ATRA, ATO and G-CSF, alone or in combination. HT93 cells were treated with $1 \mu \mathrm{M}$ ATRA, $0.125 \mu \mathrm{M}$ ATO and $50 \mathrm{ng} / \mathrm{ml} \mathrm{G}$-CSF, alone or in combination, for 8 days. (A) Morphological changes induced by ATRA, ATO and G-CSF, alone or in combination were evaluated by Wright-Giemsa staining. (B) Expression profiles of CD11b, CD11c, CD15 and $\mathrm{CD} 34$ were evaluated by flow cytometry. Three or more experiments were performed and results are shown as mean $\pm \mathrm{SD}$. ${ }^{*} \mathrm{P}<0.05 \mathrm{vs}$. control; ${ }^{\dagger} \mathrm{P}<0.05 \mathrm{vs}$. ATRA; ${ }^{\S} \mathrm{P}<0.05$ vs. ATO; ${ }^{*} \mathrm{P}<0.05$ vs. ATRA+ATO by Student's t-test.

for 4 days, apoptosis induction was determined by Apoptosis Detection kit I. Similar to previous findings that ATO induced apoptosis at concentrations ranging from 1 to $2 \mu \mathrm{M}$ in vivo and in vitro $(6,13,14)$, the same range of concentrations of ATO significantly induced apoptosis in HT93A cells in a dosedependent manner (Fig. 1B). The addition of $1 \mu \mathrm{M}$ ATRA and/ or $50 \mathrm{ng} / \mathrm{ml} \mathrm{G}$-CSF to $2 \mu \mathrm{M}$ ATO did not affect apoptosis compared to ATO treatment alone. Total apoptotic cell ratio was $38.2 \%$ in ATO+ATRA and $34.6 \%$ in ATO+ATRA+G-CSF treated cells, respectively. The ratio was not different between ATO alone, ATO+ATRA and ATO+ATRA+G-CSF groups (data not shown).

Differentiation of HT93A cells by ATO, ATRA and G-CSF. To clarify the expression profiling of differentiation markers of HT93A cells, the expression of 23 surface markers was 

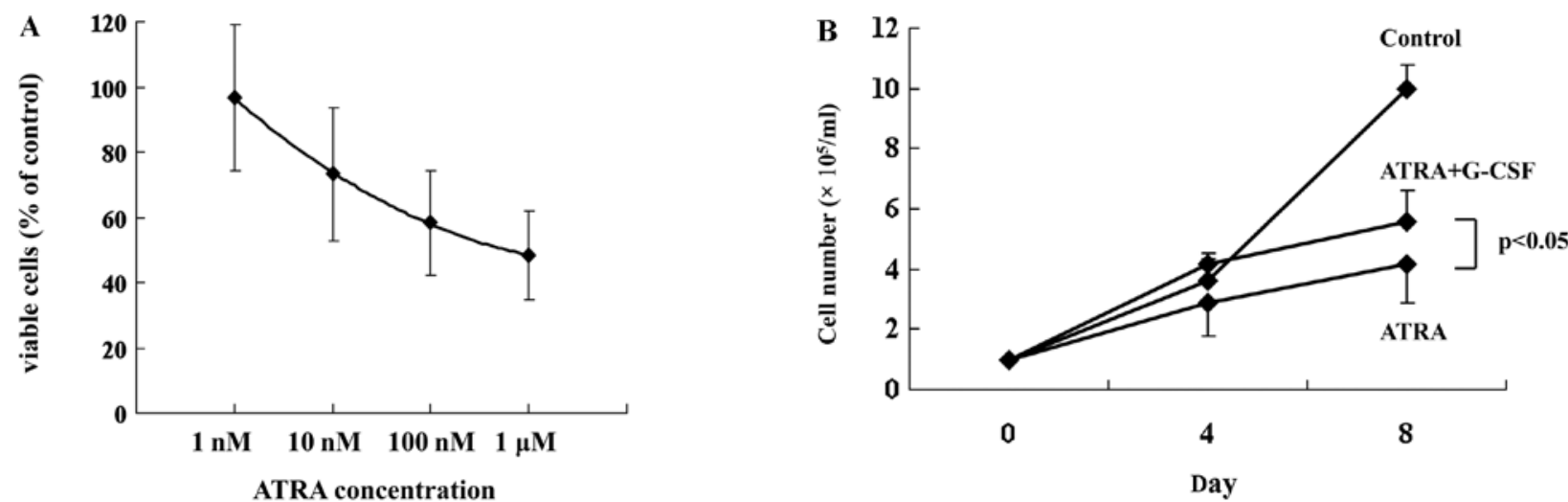

Figure 3. Dose-dependent growth inhibition by ATRA and growth recovery by combination with G-CSF in HT93A cells. (A) After treatment with ATRA $(1 \mathrm{nM}-1 \mu \mathrm{M})$ for 7 days, viable cells were measured. (B) After treatment with $1 \mu \mathrm{M}$ ATRA in the presence or absence of $50 \mathrm{ng} / \mathrm{ml} \mathrm{G}$-CSF for 4 and 8 days, viable cell number was calculated by the trypan blue dye exclusion assay. Experiments were performed three times and results are shown as mean \pm SD.

comprehensively investigated after $1 \mu \mathrm{M}$ of ATRA for 8 days. CD11b, CD11c and CD15, associated with myeloid maturation, were significantly upregulated by ATRA treatment. On the contrary, the expression of CD34, associated with progenitor cells, was significantly decreased. Therefore, we used these markers for further differentiation experiments (Table I).

After treatment with ATRA $(1 \mu \mathrm{M})$, ATO $(0.125 \mu \mathrm{M})$ and G-CSF (50 ng/ml), alone or in combination, morphological changes in HT93A cells were examined (Fig. 2A). HT93A cells treated with $1 \mu \mathrm{M}$ ATRA for 8 days underwent remarkable differentiation-associated changes with condensation and lobulation of nuclei. The differentiation-inducing activities of these reagents were assessed by examining alterations in CD11b, CD11c, CD15 and CD34 expression (Fig. 2B). Alterations in the expression of cell surface markers including a significant increase in CD11b, CD11c and CD15 and a significant decrease in CD34 concurred with the morphological changes. Furthermore, the number of cells containing multilobulated nuclei was further increased when the cells were treated with the combination of ATRA and G-CSF compared to when treated with ATRA alone. The increase in differentiation-inducing activities due to combination treatment was confirmed by a significant increase in CD11b and CD11c expression and a significant decrease in CD34 expression.

Similar to a previous report in which a low dose of ATO (0.1-0.5 $\mu \mathrm{M})$ induced differentiation of NB4 cells (13), $0.125 \mu \mathrm{M}$ ATO also induced differentiation in HT93A cells as confirmed by the appearance of jelly bean-shaped nuclei in almost all cells, accompanied by a significant increase in CD11c and CD15 expression. When cells were treated with the combination of ATO and G-CSF, G-CSF augmented differentiation by ATO, as confirmed by the observation of multi-lobulated nuclei and increased CD11b expression. No differentiation induction was observed in HT93A cells treated with G-CSF alone. Furthermore, ATO augmented morphological changes by ATRA as indicated by the appearance of an increasing number of cells containing multi-lobulated nuclei, whereas the expression surface markers did not change as compared to that observed when with ATRA alone.

CD11b expression in ATRA+ATO+G-CSF-treated cells was higher than that in ATRA+ATO-treated cells. However, $\mathrm{CD} 11 \mathrm{~b}$ and CD11c expression was significantly lower than that in ATRA+G-CSF-treated cells $(\mathrm{P}<0.01)$. Furthermore, fewer ATRA+ATO+G-CSF-treated cells showed multi-lobulated nuclei than ATRA+G-CSF-treated cells. Therefore, the combination of ATRA and G-CSF showed maximum differentiation, which was inhibited by ATO addition.

Effects of ATRA alone or in combination with G-CSF on cell viability. Treatment with ATRA for 7 days inhibited growth in a dose-dependent manner, as observed by the trypan blue dye exclusion assay (Fig. 3A). Because G-CSF stimulates growth of leukemia cells, the effect of G-CSF on cell growth in HT93A cells treated with or without ATRA was investigated. The addition of $50 \mathrm{ng} / \mathrm{ml} \mathrm{G-CSF}$ to ATRA significantly increased the number of viable cells (Fig. 3B).

Upregulation of AQP9 expression in HT93A cells by ATRA and ATO. AQP9 expression in ATRA-treated HT93A cells was investigated using flow cytometry. As shown in Fig. 4A, after treatment with ATRA $(1 \mu \mathrm{M})$ for 7 days, ATRA significantly upregulated AQP9 in HT93A cells. ATO also induced AQP9 expression, although expression was lower than that observed with ATRA. G-CSF addition did not enhance AQP9 expression in either ATRA- or ATO-treated cells (Fig. 4B). Moreover, G-CSF alone did not affect AQP9 expression (data not shown), indicating no apparent effect of G-CSF on AQP9 expression. Time-dependent upregulation of AQP9 expression was observed when cells were treated with $1 \mu \mathrm{M}$ ATRA for 4 and 7 days (Fig. 4C). Furthermore, dose-dependent upregulation of AQP9 was observed when HT93A cells were treated with various concentrations of ATRA $(1 \mathrm{nM}-1 \mu \mathrm{M})$ for 7 days (Fig. 4D), accompanied by ATRA-induced differentiation (Fig. 4E).

As [intra] in HT93A cells treated with ATRA alone or in combination with G-CSF. Arsenic uptake was measured to examine whether increased AQP9 expression contributes to ATO uptake. After treatment with $10 \mathrm{nM}$ or $1 \mu \mathrm{M}$ ATRA in the presence or absence of $50 \mathrm{ng} / \mathrm{ml} \mathrm{G}$-CSF for 7 days and exposure to $0.5 \mu \mathrm{M}$ ATO for 30, 60 and $120 \mathrm{~min}$, As[intra] was determined using ICP-MS. Compared to the control group exposed with ATO alone, As[intra] significantly decreased to $42.3 \%$ and $70.7 \%$ due to treatment with either $10 \mathrm{nM}$ or $1 \mu \mathrm{M}$ 


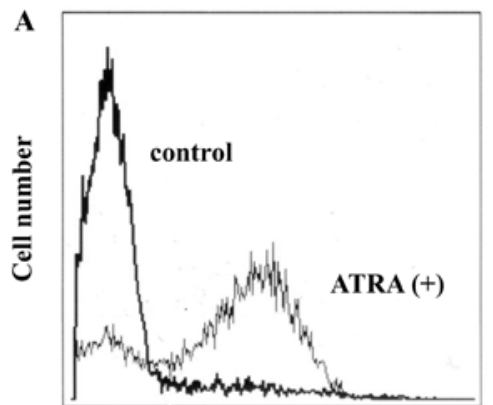

AQP9 intensity

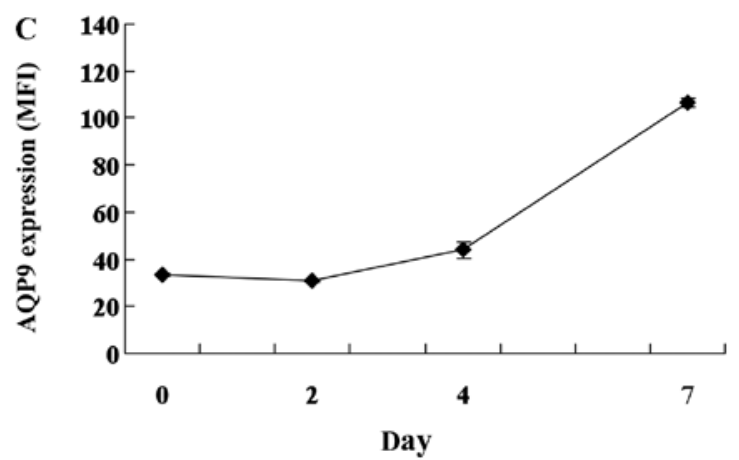

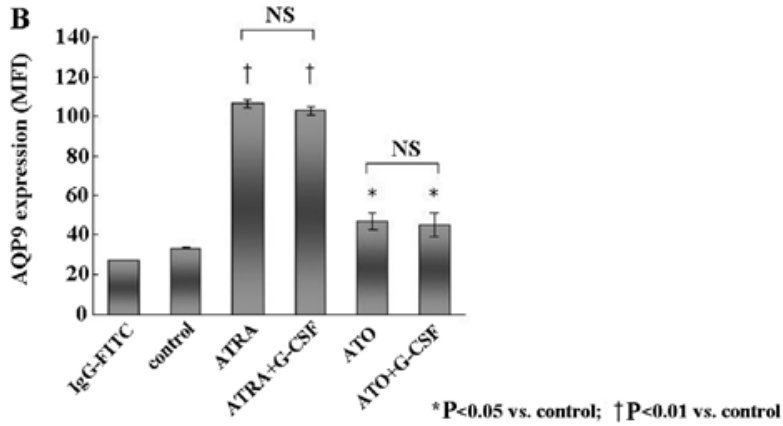

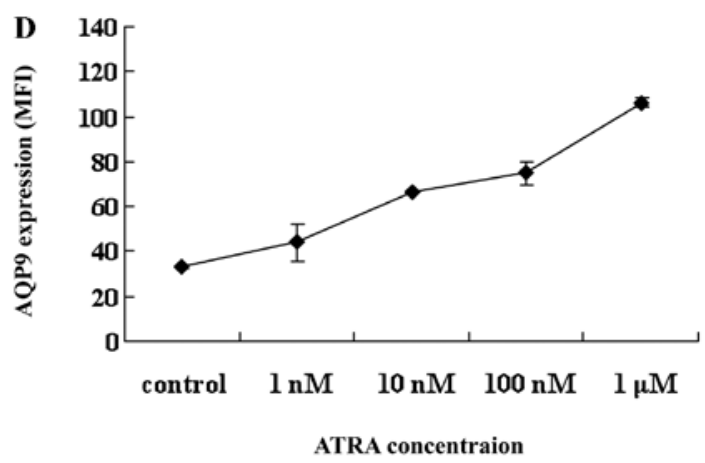

E

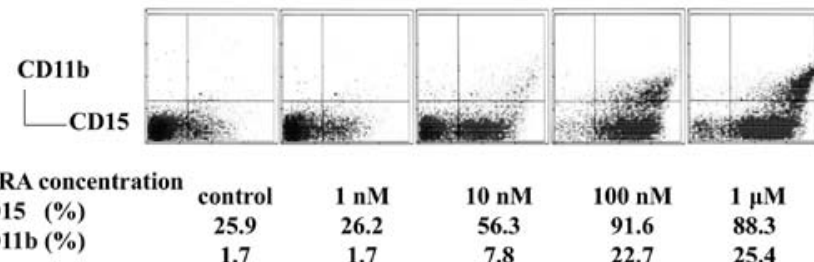

Figure 4. Effects of G-CSF in combination with ATRA or ATO on AQP9 expression in HT93A cells. HT93A cells were treated with $1 \mu \mathrm{M}$ ATRA, $0.125 \mu \mathrm{M}$ ATO and $50 \mathrm{ng} / \mathrm{ml} \mathrm{G-CSF}$, alone or in combination, for 7 days. (A) Representative histogram of AQP9 expression in HT93A cells is shown. Cells were treated with $1 \mu \mathrm{M}$ ATRA for 7 days followed by AQP9 staining. (B) Effects of ATRA and ATO in the presence or absence of G-CSF on AQP9 expression. Experiments were performed three times and results are shown as mean $\pm \mathrm{SD}$. ${ }^{*} \mathrm{P}<0.05$ vs. control; ${ }^{\dagger} \mathrm{P}<0.01$ vs. control by Student's t-test. (C) Time course of AQP9 expression when treated with $1 \mu \mathrm{M}$ ATRA for 2, 4 and 7 days. Experiments were performed three times and results are shown as mean \pm SD. (D) Dose-dependent upregulation of AQP9 when treated with each concentration of ATRA $(1 \mathrm{nM}-1 \mu \mathrm{M})$ for 7 days. Experiments were performed three times and results are shown as mean \pm SD. (E) Histogram of dose-dependent differentiation induction by ATRA treatment for 7 days.

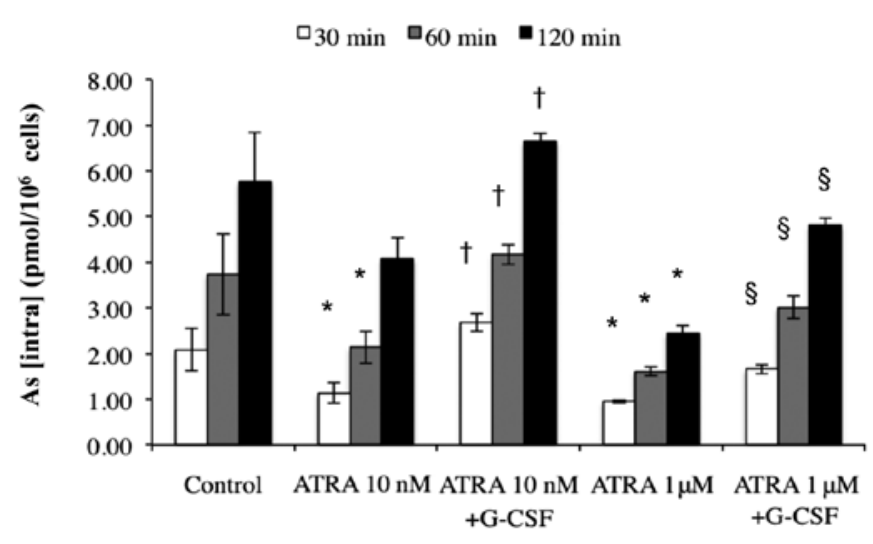

${ }^{*} \mathrm{P}<0.05$ vs. control; $\dagger \mathrm{P}<0.05$ vs. ATRA $10 \mathrm{nM} ; \S \mathrm{P}<0.05$ vs. ATRA $1 \mu \mathrm{M}$

Figure 5. As[intra] in ATRA+G-CSF-treated HT93A cells exposed to ATO. After treatment with $10 \mathrm{nM}$ or $1 \mu \mathrm{M}$ ATRA in the presence or absence of $50 \mathrm{ng} / \mathrm{ml} \mathrm{G}-\mathrm{CSF}$ for 7 days and followed by exposure to $0.5 \mu \mathrm{M}$ ATO for 30 , 60 and $120 \mathrm{~min}$, As[intra] was measured. Experiments were performed three times and results are shown as mean $\pm \mathrm{SD}$. ${ }^{*} \mathrm{P}<0.05$ vs. control; ${ }^{\dagger} \mathrm{P}<0.05$ vs. ATRA $(10 \mathrm{nM}) ;{ }^{\S} \mathrm{P}<0.05$ vs. ATRA $(1 \mu \mathrm{M})$ by Student's t-test.
ATRA for $120 \mathrm{~min}$, respectively. However, it should be noted that G-CSF addition recovered As[intra] to control levels (Fig. 5). G-CSF alone did not affect arsenic uptake (data not shown).

\section{Discussion}

In this study, we demonstrated for the first time that ATO induced growth inhibition and apoptosis in HT93A cells. ATO $(\geq 1 \mu \mathrm{M})$ significantly induced apoptosis in HT93A cells, which is similar to that observed in NB4 cells (14). Lower concentration of ATO induced differentiation of HT93A cells. On the basis of our previous study, in which the blood level of ATO in APL patients was investigated $(24,25)$, plasma concentration of ATO in either bone marrow or peripheral blood kept the effective level of differentiation induction for HT93A cells. Next, we demonstrated that both ATRA and ATO induced differentiation in HT93A cells. The differentiation induced by ATO was lesser than that induced by ATRA, as previously reported $(13,14)$. We observed the induction of 
the surface antigen CD15, but not CD11b, after treatment with ATO in HT93A cells. CD15 is an arsenic-induced sensitive differentiation marker as shown in clinical studies (26). It is noteworthy that CD34 expression, well-known to be present in hematopoietic progenitor cells and absent in NB4 cells $(8,18)$, significantly decreased after treatment with ATRA in HT93A cells. These results suggest that CD34, CD11b and CD15 could be used as a parameter to evaluate the level of differentiation in clinical therapy as shown in our previous clinical observation (25). There are only a few APL cell lines and most in vitro experiments are performed with NB4 cells. Because HT93A cells induced differentiation and apoptosis with ATO, the cell line is a useful experimental target for arsenic treatment as well as NB4 cells.

In agreement with previous reports (20), we demonstrated that G-CSF augmented differentiation induced by ATO in HT93A cells. ATO increases mRNA and protein levels of p21/WAF1 (27) which inhibits cell cycle in the $S$ phase. In concurrent use with G-CSF and ATO, it is possible that G-CSF recruits quiescent leukemic cells to the $S$ phase, rendering them more sensitive to ATO. Similar increase of CD11b and CD11c expression was observed when G-CSF was added to ATRA. Among several combinations, maximum differentiation was observed with the combination of ATRA and G-CSF. It has been shown that G-CSF restores ATRA sensitivity in APL cells both in vitro and in vivo, possibly through G-CSF receptors (9,28-31). These previous findings and our results suggest that therapeutic strategies based on ATRA or ATO in combination with G-CSF may improve the clinical efficacy of differentiation therapy against APL.

A meta-analysis of recent clinical trials with the combination of ATRA and ATO treatment of APL indicates favorable outcomes compared to ATO alone (19). However, it is still unclear whether this combination is better than ATRA alone. Dai et al (32) reported that complete remission rates in ATRA- and ATRA+ATO-treated patients with APL were similar (>90\%). Furthermore, in our experiment, ATO addition did not enhance ATRA-induced differentiation except for morphological changes, probably because ATRA functioned well.

AQP9 is responsible for transporting small uncharged molecules and plays a crucial role in arsenic uptake $(12,33)$. Previous studies demonstrated that pretreatment of a myeloid leukemia cell line HL-60 with ATRA or vitamin D upregulates AQP9 expression, leading to a significant increase in arsenic uptake and ATO-induced cytotoxicity in the presence of ATO (12,34). However, a synergistic effect of ATRA and ATO was not observed in differentiation and apoptosis in HT93A cells. We demonstrated for the first time that As[intra] decreased after treatment with ATRA, although AQP9 expression increased. Jing et al (35) reported that the pretreatment with ATRA decreased ATO-induced apoptosis in ATRAsensitive NB4 cells, but not in ATRA-resistant cells. Possibly because HT93A cells were ATRA-sensitive, a synergistic effect between ATRA and ATO was not shown.

It is worth indicating that G-CSF addition significantly recovered As[intra], whereas AQP9 expression remained the same as that when treated with ATRA alone. It has been reported that growth factors including G-CSF have multiple properties that may affect the fate of both normal and neoplastic cells; these properties include promotion of proliferation, survival and differentiation $(9,16,17)$. In fact, G-CSF transiently initiates and promotes the growth of responding acute myeloid leukemia cells but long-term proliferation is not sustained (16). G-CSF increased the number of viable HT93A cells. We speculate that ATRA decreased cell viability and, consequently, low cell metabolism resulted in reduced arsenic uptake by ATRA-sensitive cells. G-CSF may enhance arsenic uptake through increased cell viability.

In summary, we report for the first time the effects of ATO on HT93A cells, showing that ATO induced differentiation at low concentrations and apoptosis at high concentrations. We also report that G-CSF not only promoted differentiation-inducing activities of both ATRA and ATO but also made APL cells vulnerable to increased arsenic uptake, although G-CSF alone showed no influence on these cellular responses. The combination of ATRA and G-CSF showed maximum differentiation and ATO addition was not beneficial. Thus, our observations provide new insight into combination therapy with ATRA, ATO and G-CSF for the treatment of APL.

\section{Acknowledgements}

We thank Dr Kenji Kishi and Dr Yuko Sato for providing the HT93A cell line. We also thank Eiko Ishizuka for technical assistance. This work was supported in part by grants from Japan China Medical Association to B.Y.

\section{References}

1. Goddard AD, Borrow J, Freemont PS and Solomon E: Characterization of a zinc finger gene disrupted by the $t(15 ; 17)$ in acute promyelocytic leukemia. Science 254: 1371-1374, 1991.

2. Tong JH, Dong S, Geng JP, Huang W, Wang ZY, Sun GL, Chen SJ, Chen Z, Larsen CJ and Berger R: Molecular rearrangements of the MYL gene in acute promyelocytic leukemia (APL, M3) define a breakpoint cluster region as well as some molecular variants. Oncogene 7: 311-316, 1992.

3. de Thé H, Chomienne C, Lanotte M, Degos L and Dejean A: The $t(15 ; 17)$ translocation of acute promyelocytic leukaemia fuses the retinoic acid receptor alpha gene to a novel transcribed locus. Nature 347: 558-561, 1990.

4. Melnick A and Licht JD: Deconstructing a disease: RAR $\alpha$, its fusion partners, and their roles in the pathogenesis of acute promyelocytic leukemia. Blood 93: 3167-3215, 1999.

5. Burnett AK, Grimwade D, Solomon E, Wheatley K and Goldstone AH: Presenting white blood cell count and kinetics of molecular remission predict prognosis in acute promyelocytic leukemia treated with all-trans retinoic acid: result of the Randomized MRC Trial. Blood 93: 4131-4143, 1999.

6. Shen ZX, Chen GQ, Ni JH, Li XS, Xiong SM, Qiu QY, Zhu J, Tang W, Sun GL, Yang KQ, et al: Use of arsenic trioxide $\left(\mathrm{As}_{2} \mathrm{O}_{3}\right)$ in the treatment of acute promyelocytic leukemia (APL): II. Clinical efficacy and pharmacokinetics in relapsed patients. Blood 89: 3354-3360, 1997.

7. Soignet SL, Maslak P, Wang ZG, Jhanwar S, Calleja E, Dardashti LJ, Corso D, DeBlasio A, Gabrilove J, Scheinberg DA, et al: Complete remission after treatment of acute promyelocytic leukemia with arsenic trioxide. N Engl J Med 339: 1341-1348, 1998.

8. Lanotte M, Martin-Thouvenin V, Najman S, Balerini P, Valensi F and Berger R: NB4, a maturation inducible cell line with $\mathrm{t}(15 ; 17)$ marker isolated from a human acute promyelocytic leukemia (M3) Blood 77: 1080-1086, 1991.

9. Matsui W, Smith BD, Vala M, Beal N, Huff CA, Diehl LF and Jones RJ: Requirement for myeloid growth factors in the differentiation of acute promyelocytic leukaemia. Br J Haematol 128: 853-862, 2005. 
10. Caprodossi S, Pedinotti M, Amantini C, Santoni G, Minucci S, Pelicci PG and Fanelli M: Differentiation response of acute promyelocytic leukemia cells and PML/RAR $\alpha$ leukemogenic activity studies by real-time RT-PCR. Mol Biotechnol 30: 231-238, 2005.

11. Cunha De Santis G, Tamarozzi MB, Sousa RB, Moreno SE, Secco D, Garcia AB, Lima AS, Faccioli LH, Falcão RP, Cunha FQ and Rego EM: Adhesion molecules and Differentiation Syndrome: phenotypic and functional analysis of the effect of ATRA, $\mathrm{As}_{2} \mathrm{O}_{3}$, phenylbutyrate, and G-CSF in acute promyelocytic leukemia. Haematologica 92: 1615-1622, 2007.

12. Leung J, Pang A, Yuen WH, Kwong YL and Tse EW: Relationship of expression of aquaglyceroporin 9 with arsenic uptake and sensitivity in leukemia cells. Blood 109: 740-746, 2007.

13. Chen GQ, Shi XG, Tang W, Xiong SM, Zhu J, Cai X, Han ZG, $\mathrm{Ni} \mathrm{JH}$, Shi GY, Jia PM, et al: Use of arsenic trioxide $\left(\mathrm{As}_{2} \mathrm{O}_{3}\right)$ in the treatment of acute promyelocytic leukemia (APL): $\mathrm{I}$. $\mathrm{As}_{2} \mathrm{O}_{3}$ exerts dose-dependent dual effects on APL cells. Blood 89: 3345-3353, 1997.

14. Chen GQ, Zhu J, Shi XG, Ni JH, Zhong HJ, Si GY, Jin XL, Tang W, Li XS, Xong SM, et al: In vitro studies on cellular and molecular mechanisms of arsenic trioxide $\left(\mathrm{As}_{2} \mathrm{O}_{3}\right)$ in the treatment of acute promyelocytic leukemia: $\mathrm{As}_{2} \mathrm{O}_{3}$ induces $\mathrm{NB}$ cell apoptosis with downregulation of $\mathrm{Bcl}-2$ expression and modulation of PML-RAR $\alpha /$ PML proteins. Blood 88: 1052-1061, 1996.

15. Yoshino Y, Yuan B, Kaise T, Takeichi M, Tanaka S, Hirano T, Kroetz DL and Toyoda H: Contribution of aquaporin 9 and multidrug resistance-associated protein 2 to differential sensitivity to arsenite between primary cultured chorion and amnion cells prepared from human fetal membranes. Toxicol Appl Pharmacol 257: 198-208, 2011.

16. Pébusque MJ, Lafage M, Lopez M and Mannoni P: Preferential response of acute myeloid leukemias with translocation involving chromosome 17 to human recombinant granulocyte colonystimulating factor. Blood 72: 257-265, 1998.

17. Souza LM, Boone TC, Gabrilove J, Lai PH, Zsebo KM, Murdock DC, Chazin VR, Bruszewski J, Lu H, Chen KK, et al: Recombinant human granulocyte colony-stimulating factor: effects on normal and leukemic myeloid cells. Science 232 : 61-65, 1986.

18. Hu J, Liu YF, Wu CF, Xu F, Shen ZX, Zhu YM, Li JM, Tang W, Zhao WL, Wu W, et al: Long-term efficacy and safety of all-trans retinoic acid/arsenic trioxide-based therapy in newly diagnosed acute promyelocytic leukemia. Proc Natl Acad Sci USA 106 3342-3347, 2009.

19. Wang H, Chen XY, Wang BS, Rong ZX, Qi H and Chen HZ: The efficacy and safety of arsenic trioxide with or without all-trans retinoic acid for the treatment of acute promyelocytic leukemia: a meta-analysis. Leuk Res 35: 1170-1177, 2011.

20. Kishi K, Toba K, Azegami T, Tsukada N, Uesugi Y, Masuko M, Niwano H, Hashimoto S, Sakaue M, Furukawa T, et al: Hematopoietic cytokine-dependent differentiation to eosinophils and neutrophils in a newly established acute promyelocytic leukemia cell line with $\mathrm{t}(15 ; 17)$. Exp Hematol 26: 135-142, 1998

21. Iijima Y, Ito T, Oikawa T, Eguchi M, Eguchi-Ishimae M, Kamada N, Kishi K, Asano S, Sakaki Y and Sato Y: A new ETV6/TEL partner gene, ARG (ABL-related gene or ABL2), identified in an AML-M3 cell line with a $\mathrm{t}(1 ; 12)(\mathrm{q} 25 ; \mathrm{p} 13)$ translocation. Blood 95: 2126-2131, 2000.

22. Makishima M, Umesono K, Shudo K, Naoe T, Kishi K and Honma Y: Induction of differentiation in acute promyelocytic leukemia cells by 9 -cis retinoic acid alpha-tocopherol ester (9-cis tretinoin tocoferil). Blood 91: 4715-4726, 1998.
23. Uesugi Y, Fuse I, Toba K, Kishi K, Furukawa T, Koike T and Aizawa Y: Involvement of SHP-1, a phosphotyrosine phosphatase, during myeloid cell differentiation in acute promyelocytic leukemia cell lines. Eur J Haematol 62: 239-245, 1999.

24. Yoshino Y, Yuan B, Miyashita SI, Iriyama N, Horikoshi A, Shikino O, Toyoda $\mathrm{H}$ and Kaise T: Speciation of arsenic trioxide metabolites in blood cells and plasma of a patient with acute promyelocytic leukemia. Anal Bioanal Chem 393: 689-697, 2009.

25. Iriyama N, Yoshino Y, Yuan B, Horikoshi A, Hirabayashi Y, Hatta Y, Toyoda $\mathrm{H}$ and Takeuchi J: Speciation of arsenic trioxide metabolites in peripheral blood and bone marrow from an acute promyelocytic leukemia patient. J Hematol Oncol 5: 1-11, 2012.

26. Shao W, Fanelli M, Ferrara FF, Riccioni R, Rosenauer A, Davison K, Lamph WW, Waxman S, Pelicci PG, Lo Coco F, et al: Arsenic trioxide as an inducer of apoptosis and loss of PML/RAR $\alpha$ protein in acute promyelocytic leukemia cells. J Natl Cancer Inst 90: 124-133, 1998.

27. Wang X, Gao P, Long M, Lin F, Wei JX, Ren JH, Yan L, He T, Han Y and Zhang HZ: Essential role of cell cycle regulatory genes p21 and p27 expression in inhibition of breast cancer cells by arsenic trioxide. Med Oncol 28: 1225-1254, 2011.

28. Higuchi T, Kizaki M and Omine M: Induction of differentiation of retinoic acid-resistant acute promyelocytic leukemia cells by the combination of all-trans retinoic acid and granulocyte colony-stimulating factor. Leuk Res 28: 525-532, 2004.

29. Jansen JH, de Ridder MC, Geertsma WM, Erpelinck CA, van Lom K, Smit EM, Slater R, vd Reijden BA, de Greef GE, Sonneveld $\mathrm{P}$ and Löwenberg B: Complete remission of $\mathrm{t}(11 ; 17)$ positive acute promyelocytic leukemia induced by all-trans retinoic acid and granulocyte colony-stimulating factor. Blood 94: 39-45, 1999.

30. Tsurumi H, Tojo A, Takahashi T, Moriwaki H, Asano S and Muto Y: The combined effects of all-trans retinoic acid and granulocyte colony-stimulating factor as a differentiation induction therapy for acute promyelocytic leukemia. Intern Med 32: 648-650, 1993.

31. Gianní M, Terao M, Zanotta S, Barbui T, Rambaldi A and Garattini E: Retinoic acid and granulocyte colony-stimulating factor synergistically induce leukocyte alkaline phosphatase in acute promyelocytic leukemia cells. Blood 83: 1909-1921, 1994.

32. Dai CW, Zhang GS, Shen JK, Zheng WL, Pei MF, Xu YX, Cao YX, Yi Y, Yang JJ, Peng HL, et al: Use of all-trans retinoic acid in combination with arsenic trioxide for remission induction in patients with newly diagnosed acute promyelocytic leukemia and for consolidation/maintenance in CR patients. Acta Haematol 121: 1-8, 2009.

33. Shinkai Y, Sumi D, Toyama T, Kaji T and Kumagai Y: Role of aquaporin 9 in cellular accumulation of arsenic and its cytotoxicity in primary mouse hepatocytes. Toxicol Appl Pharmacol 237: 232-236, 2009

34. Bhattacharjee H, Carbrey J, Rosen BP and Mukhopadhyay R: Drug uptake and pharmacological modulation of drug sensitivity in leukemia by AQP9. Biochem Biophys Res Commun 322: 836-841, 2004

35. Jing Y, Wang L, Xia L, Chen GQ, Chen Z, Miller WH and Waxman S: Combined effect of all-trans retinoic acid and arsenic trioxide in acute promyelocytic leukemia cells in vitro and in vivo. Blood 97: 264-269, 2001. 